Corresponding Author: Andrey

A. Kovalev; email:

kovalev_ana@mail.ru

Dates

Published 13 January 2022

Publishing services provided by Knowledge E

(c) Andrey A. Kovalev et al. This article is distributed under the terms of the Creative Commons Attribution License, which permits unrestricted use and redistribution provided that the original author and source are credited.

Selection and Peer-review under the responsibility of the 8 th Scientific and Practical Conference Conference Committee.

\section{Energy rationale for the Use of the Thermophilic Mode of Anaerobic Bioconversion of Liquid Organic Waste in the Climatic Conditions of the Russian Federation}

Andrey A. Kovalev ${ }^{1}$, Dmitriy A. Kovalev ${ }^{1}$, Yuri V. Litti ${ }^{2}$, Inna V. Katraeva ${ }^{3}$, and Alla N. Nozhevnikova ${ }^{2}$

${ }^{1}$ Federal Scientific Agroengineering Center VIM, 109428, Russia, Moscow

${ }^{2}$ Federal Research Centre «Fundamentals of Biotechnology» of the Russian Academy of Sciences, 119071, Russia, Moscow

${ }^{3}$ Nizhny Novgorod State University of Architecture and Civil Engineering (NNSAGU), 603950, Russia, Nižnij Novgorod

\section{ORCID}

Andrey A. Kovalev; 0000-0002-1983-3454

Abstract. The transition of livestock production to industrial processes and the concentration of animals associated with this process on large farms and complexes has caused a sharp increase in the volume of manure that must be disposed of without pollution. One of the ways of processing organic waste (biomass) is its anaerobic digestion in biogas plants through the vital activity of microorganisms (methanogenesis).Biogas obtained using microbiological processing of biomass can be used as a raw material for heat and electric energy. Annually, $0.17 \%$ of the total livestock manure produced at Russian agricultural enterprisesis used for biogas production. The main component of a biogas plant is a manure fermentation reactor, the required volume of which is determined by the daily output of manure from the livestock farm, the temperature and the hydraulic retention time of treatment. This research explored thermal energy consumption of biogas plants, using the example of a biogas plant of a modular design that depended on the average annual outdoor temperature. Based on the calculations, the thermophilic mode was found to be more energy-efficient than the mesophilic one; thus, with the thermophilic mode, the specific energy consumption needed for the plant was lower at the average annual outdoor temperatures of all the constituent entities of the Russian Federation. At the same time, the specific biogas yield in the thermophilic regime was $20-50 \%$ higher than in the mesophilic regime.

Keywords: anaerobic processing, agricultural waste, thermophilicmode, mesophilicmode, energy costs, energy rationale

\section{Introduction}

The transition of livestock production to an industrial basis and the number of animals associated with this process on large farms and complexes cause a sharp increase in the volume of manure that must be disposed of in order to prevent environmentalpollution. 
The problem of recycling livestock, poultry and crop wastes is relevant for the agricultural industry, since the amount of waste from the agricultural sector of Russia today reaches 773 million tons per year, and a significant part of this waste is not disposed of.This leads to problems of soil acidification, alienation of agricultural land (more than 2 million hectares of agricultural land is used for manure storage), pollution of groundwater, and emissions of methane, which is a greenhouse gas, into the atmosphere.Therefore, waste requires the use of costly technologies for their disinfection and special conditions for their storage. [1]

The annual consumption of livestock waste for biogas production is $0.17 \%$ of the total manure produced at Russian agricultural enterprises. [2]

One of the ways of processing organic waste (biomass) is their anaerobic digestion in biogas plants due to the vital activity of microorganisms (methanogenesis), when biogas is obtained using microbiological processing of biomass and used, in turn, as a raw material for heat and electric energy.

Biogas technologies have long been used in the agricultural industry. There are many new concepts and technological solutions to improve the efficiency and intensification of processes in biogas plants that have never found application in industry.

The development, design and construction of new and modification of existing reactors for biogas production from various agricultural wastes are designed to solve a number of significant energy and environmental problems:

- toreduce anthropogenic pressure on ecosystems;

- toreduce harmful greenhouse gas emissions;

- fully utilize and recycle organic waste;

- to ensure the objects uninterrupted power and heat supply of their own needs;

- by using various technological solutions to obtain high-quality products from digester effluent, which can be used as fertilizers, feed additives or bedding for animals.[1]

Thus, at present, the actual use of organic waste potentially suitable for biogas production is $2-3$ orders of magnitude lower than the existing potential for organic waste.[2]

Therefore, the development of biogas production technologies is an urgent problem, the solution of which will make it possible to effectively use the energy potential of organic waste of the agro-industrial complex while reducing its negative impact on the environment. 


\section{Background}

The main link in a biogas plant is a manure fermentation reactor, the required volume of which is determined by the daily output of manure from the livestock farm, the temperature and duration of treatment.

In turn, the daily output of manure depends on the type and stock of animals or poultry, and in accordance with accepted standards can be from 2 to 200 tons per day for farms from 50 to 5000 conventional heads of cattle.

So for the most common type of cattle farm in Russia for 400 heads, the total amount of waste generatedcan range from 20 to $30 \mathrm{~m}^{3}$ per day. For anaerobic processing of such a quantity of waste, it will be necessary to build a reactor with a volume of 300 to $600 \mathrm{~m}^{3}$, depending on the retention time of the substrate in the reactor, which in turn depends on the processing temperature and in general is 10 days for thermophilic and 21 days for mesophilic. [1]

In order to reduce the reactor volume and, consequently, capital costs, increase biogas output, ensure sanitary standards for manure disinfection and reduce energy costs for the plant's own needs, a thermophilic treatment regime should be adopted $\left(\mathrm{T}=55^{\circ} \mathrm{C}\right)$.

From the experience of using digesters in the Russian Federationitis known that mesophilic (anaerobic and aerobic) stabilization of sewage sludge (SS)does not provide the necessary reduction of pathogenic bacteria and helminth eggs. This is also evidenced by foreign data. Thus, studies conducted in Sweden showed that salmonella is present in $74 \%$ of samples of primary sludge, in $70 \%$ of samples of excess sludge and in $20 \%$ of samples of SSfermented under mesophilicconditions (the number of samples of each SS is 190). Thus, with mesophilic fermentation, the amount of salmonella is reduced by $70 \%$.[3]

The number of pathogenic enterobacteria can even increaseaftermesophilic fermentation. According to Közer [4], after four-week fermentation, the SS was infected with Salmonella 2 times more than the raw one (they were found in $90 \%$ of the samples of the fermented SS, while in the raw one - in $45 \%$ of samples).

Thermophilic fermentation gives a significantly higher sanitary effect.This is evidenced by the practical experience of the Moscow aeration stations (waste watertreatment facilities). Table 1 shows the data on the influence of mesophilic and thermophilic anaerobic digestion on the decrease in SS numbers of salmonella and tuberculosis bacteria. [3] 
TABLE 1: Effect of anaerobically fermented sludge on the effectiveness of its disinfection [5].

Sewage sludge
Mesophilicallyfermented
Thermophilicallyfermented
Mesophilically fermented and
dried over: 14 days
30 days

\begin{tabular}{l|l|}
\multicolumn{2}{c}{ Decrease (relative to rawSS), \% } \\
\hline Salmonella & Tuberculosisbacteria \\
\hline $50-70$ & 45 \\
$85-95$ & 100 \\
\hline $60-80$ & 21 \\
$60-90$ & 51
\end{tabular}

\section{Methods and Equipment}

The specific heat consumption for the biogasplant's own needs is:

$$
Q_{\text {pon }}=Q_{H}+Q_{K}+Q_{b g}
$$

where $Q_{H}-$ specific heat energy consumption for preliminary heating of the substrate to the fermentation temperature, $\mathrm{kW} \cdot \mathrm{h} /\left(\mathrm{kg}_{i s} /\right.$ day);

$Q$ - specific daily heat energy consumption for the compensation of heat losses from building envelopes and pipelines, $\mathrm{kW} \cdot \mathrm{h} /\left(\mathrm{kg}_{i s} /\right.$ day);

$Q_{b g}$ - specific amount of thermal energy leaving withgenerated biogas, $\mathrm{kW} \cdot \mathrm{h} /\left(\mathrm{kg}_{i s} /\right.$ day).

The specific heat consumption for preheating the substrate $\left[\mathrm{kW} \cdot \mathrm{h} /\left(\mathrm{kg}{ }_{i s} / \mathrm{day}\right)\right]$ is defined as

$$
Q_{H}=\frac{C_{H} \bullet\left(T_{H}-T_{1}\right) \bullet h r t}{3,6}
$$

where $C_{H}$ - heat capacity of the substrate, $\mathrm{kJ} /\left(\mathrm{kg}_{i s} \bullet{ }^{\circ} \mathrm{C}\right)$;

$T$ - final substrate heating temperature - anaerobic digestion temperature, ${ }^{\circ} \mathrm{C}$;

$T_{1}-$ initial substrate temperature, ${ }^{\circ} \mathrm{C}$;

hrt - hydraulic retention time, day.

Average daily specific heat consumption $\left[\mathrm{kW} \cdot \mathrm{h} /\left(\mathrm{kg}_{i s} / \mathrm{day}\right)\right]$, necessary to compensate for heat losses through the enclosing surfaces of the bioreactor at an average annual outdoor temperature

$$
Q_{K}=k \bullet F \bullet\left(T_{H}-T_{O}\right) \bullet 10^{-3} \bullet 24
$$


where $k$ - heat transfer coefficient, $\mathrm{W} /\left(\mathrm{m}^{2} \cdot \mathrm{K}\right)$;

$F-$ the area of the enclosing surfaces of the bioreactor, $\mathrm{m}^{2}$;

$T_{H}$ - substrate temperature in the bioreactor, ${ }^{0} \mathrm{C}$;

$T_{O}$ - outdoor temperature, ${ }^{\circ} \mathrm{C}$.

The area of the bioreactor enclosing surfaces depends on the geometry of the reactor, as well as on the daily loading dose:

$$
F=f(V)
$$

The specific amount of thermal energy leaving with the generated biogas $\left[\mathrm{kW} \cdot \mathrm{h} /\left(\mathrm{kg}_{i s} /\right.\right.$ day)] is defined as

$$
Q_{b g}=\frac{C_{b g} \bullet G_{b g} \bullet\left(T_{H}-T_{O}\right)}{24 * 3600}
$$

где $C_{b g}$-heat capacity of generated biogas, $\mathrm{kJ} /\left(\mathrm{kg} \cdot{ }^{\circ} \mathrm{C}\right)$; [6]

$G_{b g}-$ specific daily amount of generated biogas, $\mathrm{kg} / \mathrm{kg}_{i s}$.

The initial data for the calculation:

- bioreactor - bioreactor of modular construction with a volume of $60 \mathrm{~m}^{3}$;

- the area of the enclosing surfaces of the biorectorF $=113 \mathrm{~m}^{2}$;

- bioreactor thermal insulation - mineral wool 300 mm thick;

- heat transfer coefficient of the enclosing surfaces of the bioreactor $\mathrm{k}=0.136 \mathrm{~W} /\left(\mathrm{m}^{2} \cdot \mathrm{K}\right)$;

- heat capacity of the substrate $]=4.06 \mathrm{~kJ} /\left(\mathrm{kg}_{i s} \cdot \mathrm{K}\right)$;

- substrate density $\square_{H}=1020 \mathrm{~kg} / \mathrm{M} 3$,

- initial substrate temperature $\mathrm{T}_{1}$ equal to $4^{\circ} \mathrm{C}$ at average annual outdoor temperatures below $5^{\circ} \mathrm{C}$;

- at average annual outdoor temperatures above $5^{\circ} \mathrm{C}$, the temperature of the initial substrate $T_{1}$ is taken equal to the temperature of the outdoor air.

Based on the collection of Rosstat "Agriculture, hunting and forestry in Russia. 2009 "the climatic norm of January in Russia is $-19.7^{\circ} \mathrm{C}$ (in 2008 , the actual temperature was $\left.-19.1^{\circ} \mathrm{C}\right)$, including in:

Central Federal District $-9.4^{\circ} \mathrm{C}$ (in $2008-7.7^{\circ} \mathrm{C}$ );

Northwestern Federal District $-12.4^{\circ} \mathrm{C}$ (in $2008-5.6{ }^{\circ} \mathrm{C}$ );

Southern Federal District $-4.2^{\circ} \mathrm{C}\left(\right.$ in $2008-7.5^{\circ} \mathrm{C}$ );

Volga Federal District $-13.4^{\circ} \mathrm{C}$ (in $2008-12.5^{\circ} \mathrm{C}$ ); 
Ural Federal District $-19.1^{\circ} \mathrm{C}$ (in $2008-16.8^{\circ} \mathrm{C}$ );

Siberian Federal District $-22.6^{\circ} \mathrm{C}$ (in $2008-24.0^{\circ} \mathrm{C}$ );

Far Eastern Federal District $-23.0^{\circ} \mathrm{C}$ (in $2008-22.7^{\circ} \mathrm{C}$ ).

The average between the minimum and maximum average January temperatures is $-28.2^{\circ} \mathrm{C}$. In January, in Russia, it is never higher than $26.7^{\circ} \mathrm{C}$, and in the Far East it is not higher than $7.1^{\circ} \mathrm{C}$.

The climatic norm of July in Russia is $+15.6^{\circ} \mathrm{C}$ (in 2008 , the actual temperature was $\left.+16.8^{\circ} \mathrm{C}\right)$, including in:

Central Federal District $+18.2{ }^{\circ} \mathrm{C}$ (in $2008+19.3^{\circ} \mathrm{C}$ );

Northwestern Federal District $+14.3^{\circ} \mathrm{C}$ (in $2008+15.0^{\circ} \mathrm{C}$ );

Southern Federal District $+22.3^{\circ} \mathrm{C}\left(\right.$ in $\left.2008+23.4{ }^{\circ} \mathrm{C}\right)$;

Volga Federal District $+19.2^{\circ} \mathrm{C}$ (in $2008+20.5^{\circ} \mathrm{C}$ );

Ural Federal District +17.3 (in $2008+19.1^{\circ} \mathrm{C}$ );

Siberian Federal District $+15.5^{\circ} \mathrm{C}$ (in $2008+16.4^{\circ} \mathrm{C}$ );

Far Eastern Federal District $+14.1^{\circ} \mathrm{C}$ (in $2008+15.3^{\circ} \mathrm{C}$ ).

The average between the minimum and maximum average July temperatures is +15.5 ${ }^{\circ} \mathrm{C}$.In July, in Russia, except for the Chukotka Autonomous Okrug, no less than $-9.3^{\circ} \mathrm{C}$.

Thus, the average annual air temperature in Russia is $-5.5^{\circ} \mathrm{C}$. The range of average annual temperature at individual points in Russia is 36 degrees (from -23 to $+13^{\circ} \mathrm{C}$ ). [7]

\section{Results and Discussion}

Figure 1 shows the specific costs of thermal energy for the auxiliary needs of a biogas plant in the mesophilic and thermophilic modes depending on the ambient temperature.

As can be seen from Figure 1, the specific heat consumption for the own needs of a biogas plant in the mesophilic mode is higher than in the thermophilic one in the entire range of average annual outdoor temperatures in the territory of the Russian Federation.At the same time, the mesophilic temperature mode of biogas plants becomes more efficient from an energy point of view only at average annual outdoor temperatures above $19^{\circ} \mathrm{C}$. 


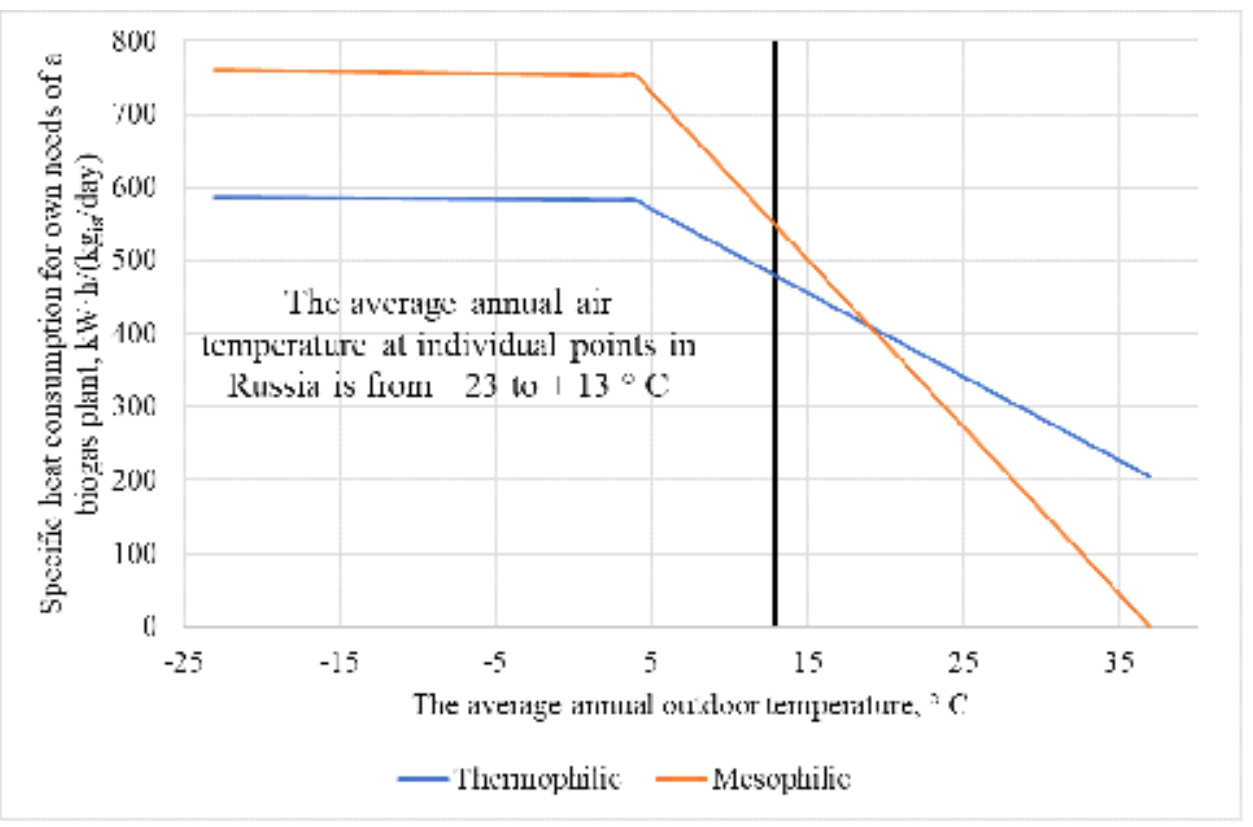

Figure 1: Specific heat consumption for own needs of a biogas plant.

\section{Conclusion}

The work explores thermal energyconsumption for the own needs of biogas plants using the example of a biogas plant of a modular design depending on the average annual outdoor temperature.

Based on the calculations, the thermophilic mode is more energy-efficient than the mesophilic one, that is, with the thermophilic mode, the specific energy consumption for the plant's own needs is lower at the average annual outdoor temperatures of all the constituent entities of the Russian Federation.

At the same time, the specific biogas yield in the thermophilicmode is higher than in the mesophilicmode by $20-50 \%$, ceteris paribus. In addition, when using the thermophilic mode of fermentation, the sanitary and hygienic hazard of the processed organic waste is significantly reduced, and the hydraulic retention time of the waste in the reactor necessary to achieve the required level of digestion of organic matter is reduced, and, as a result, the volume of the bioreactor decreases.

Thus, the use of the thermophilic temperature mode of biogas plants is more energetically rationale than the use of the mesophilic mode, since it allows:

- to treat more organic waste in the same volume reactor at anaerobic conditions;

- to generate more biogas;

- to provide a better sanitary effect. 


\section{Acknowledgment}

This work was supported by the Federal State Budgetary Institution "Russian Foundation for Basic Research" as part of scientific project No. 18-29-25042.

\section{References}

[1] Kovalev AA. Technologies and feasibility study of biogas production in systems for the disposal of manure of livestock farms(Tekhnologiiitekhnikoenergeticheskoyeobosnovaniyeproizvodstvabiogaza $v$ sistemakhutilizatsiinavozazhivotnovodcheskikhferm) [Doctoral Dissertation]. Moscow:VIESH RAAS; 1998.

[2] Namsaraev Z,Litti Y, Nozhevnikova A. Analysis of the resource potential of biogas production in the Russian Federation. Journal of Physics: Conference Series. 2018;1111(1). 1-5 doi:10.1088/1742-6596/1111/1/012012

[3] Gunter LI, Goldfarb LL. Digesters (Metantenki). Moscow:Stroyizdat; 1991.

[4] Turovsky IS. Sewage sludge treatment (Obrabotkaosadkovstochnykhvod) $3^{\text {rd }}$ edition.?oscow: Stroyizdat; 1988.

[5] Strauch D.Mikrobiologische untersuchungen zur hygieni - sierung von klarschlamm. GWS-Wasser-Abwasser. 1980;3:115-120.

[6] Kovalev AA. Improving the energy efficiency of biogas plants (Povysheniyeenergeticheskoyeffektivnostibiogazovykhustanovok) [CandidateDissertation]. Moscow: VIESH; 2014.

[7] LaikamKE. Agriculture, hunting and hunting, forestry in Russia (Sel'skoyekhozyaystvo, okhotaiokhotnich'yekhozyaystvo, lesovodstvo v Rossii). Moscow: Rosstat; 2009. 